\title{
BRIEF SUMMARIZATION OF RESEARCH'S RESULTS OF VERIFICATION OF EDUCATIVE BOX OF BRICKS DURING LESSONS OF DESIGN AND TECHNOLOGY
}

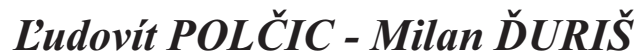

\begin{abstract}
Abstrakt: In this article the authors briefly set some results of pedagogical research by which they verified educative box of bricks Dominika in teaching process. Authors give information about the main aim of the research as well the main hypothesis and name working hypotheses. Then they concentrated on the process of verification of the box of bricks and inform about the results of tested hypotheses.
\end{abstract}

Keywords: pedagogical research, box of bricks, control group, experimental group.

\section{STRUČNÁ SUMARIZÁCIA VÝSLEDKOV Z OVERENIA EDUKAČNEJ STAVEBNICE VO VYUČOVANÍ TECHNICKEJ VÝCHOVY}

Resumé: V článku autori stručne uvádzajú niektoré výsledky z pedagogického výskumu v rámci ktorého overovali edukačnú stavebnicu Dominika vo vyučovacom v procese. Informujú o hlavnom cieli výskumu, oboznamujú s hlavnou hypotézou a vymenúvajú pracovné hypotézy. Dalej sa autori $v$ článku zamerali na postup overovania stavebnice a podávajú informáciu o výsledkoch testovaných hypotéz.

Kl'účové slová: pedagogický výskum, stavebnica, kontrolná skupina, experimentálna skupina.

\section{1 Úvod}

Ak sa má dosiahnut' patričnej efektivity výchovno-vzdelávacieho procesu, je nutné, aby žiaci boli aktivizovaní, aby sa u nich vzbudil záujem, aby sa vnútorne stotožnili s riešenou problematikou, teda aj takou, ktorá povedie $\mathrm{k}$ rozvoju technického tvorivého myslenia. Jednou z možností je využívanie hračiek ako didaktických prostriedkov vo vyučovaní. $\mathrm{V}$ príspevku stručne interpretujeme čast' výsledkov verifikácie hypotéz H1, H2 a H3, v ktorých predpokladáme, že žiaci na 2 . st. ZŠ, ktorí používali stavebnicu Dominika, dosiahnu na konci experimentálneho vyučovania vo vedomostnom teste, $\mathrm{v}$ praktickom teste a v Teste diferenciácií schopností - priestorové vzt'ahy vyšší výkon ako žiaci vyučovaní tradične v kontrolnej skupine.

\section{Stručná sumarizácia niektorých výsledkov výskumu}

Ciel'om empirického výskumu bolo overenie úspešnosti použitia stavebnice Dominika v reálnych podmienkach vybraných škôl v predmete Technická výchova.

Hlavná hypotéza:

Pri plnení ciel'ov technickej výchovy sú predpoklady na efektívne využívanie hračky stavebnice Dominika na ZŠ.
Pracovné hypotézy:

H1: Žiaci, ktorí používali stavebnicu Dominika, dosiahnu na konci experimentálneho vyučovania vo vedomostnom didaktickom teste vyšší výkon v oblasti zapamätania a špecifického transferu ako žiaci vyučovaní tradične v kontrolnej skupine.

H2: Žiaci, ktorí používali stavebnicu Dominika, dosiahnu na konci experimentálneho vyučovania v praktickom didaktickom teste vyšší výkon v oblasti špecifického transferu ako žiaci vyučovaní tradične $\mathrm{v}$ kontrolnej skupine.

H3: Žiaci, ktorí používali stavebnicu Dominika, dosiahnu na konci experimentálneho vyučovania v Teste diferenciácií schopností - priestorové vzt’ahy vyšší výkon ako žiaci vyučovaní tradične $\mathrm{v}$ kontrolnej skupine.

Výberový súbor tvorilo 140 žiakov 6. ročníka základných škôl z piatich ZŠ v SR. Aby sme mohli objektívne určit', či stavebnica Dominika ovplyvňuje úroveň technického tvorivého myslenia žiakov 6 . ročníka ZŠ v predmete Technická výchova, boli do experimentu zahrnuté dve skupiny respondentov: kontrolná a experimentálna. Kontrolnú skupinu tvorilo 70 
žiakov a experimentálnu skupinu tvorilo 70 žiakov. Na testovanie rovnocennosti testovaných skupín žiakov sme použili neštandardizovaný didaktický test vlastnej konštrukcie a štandardizovaný test priestorového myslenia TDS-PV. V teste TDS-PV ak sme vyjadrili výkon počtom získaných bodov, bolo zistené, že úroveň priestorového myslenia žiakov 6.A a 6.B. triedy sa mierne líši $\mathrm{v}$ prospech 6.A triedy. $\mathrm{Z}$ tohto dôvodu sme 6.A triedu určili ako kontrolnú skupinu. Hodnota testovacieho kritéria $\mathrm{z}=1,521$ a hodnota pravdepodobnosti $\mathrm{p}=0,020$. Rozdiely nie sú štatisticky významné na hladine významnosti 0,01 (Tab.1).

\begin{tabular}{|l|c|c|c|}
\hline Premenná & $\mathrm{D}$ & $\mathrm{z}$ & $\mathrm{p}$ \\
\hline TDSTSU & 0,25714 & 1,521 & 0,0200 -nevýzn. \\
\hline
\end{tabular}

Tab 1: Výsledky vstupného TDS-PV vyhodnotené pomocou Kolmogorov-Smirnovovho testu pre dva nezávislé výbery.

\begin{tabular}{|l|c|c|c|}
\hline Premenná & $\mathrm{D}$ & $\mathrm{z}$ & $\mathrm{p}$ \\
\hline TTSUM & 0,07143 & 0,423 & 0,9940 -nevýzn. \\
\hline
\end{tabular}

Tab 2: Výsledky vstupného vedomostného testu technickej výchovy vyhodnotené

pomocou Kolmogorov-Smirnovovho testu pre dva nezávislé výbery.

Vo vedomostnom teste technickej výchovy ak sme vyjadrili výkon počtom získaných bodov bolo zistené, že úroveň vedomostí a myslenia žiakov v 6.A a 6.B triede sa nelíši. Hodnota testovacieho kritéria $\mathrm{z}=0,423$ a hodnota pravdepodobnosti $\mathrm{p}=0,9940$. Pozorované rozdiely nie sú štatisticky významné na hladine významnosti 0,01 . Výsledky, ktoré sme dostali pomocou Kolmogorov-Smirnovovho testu pre dva nezávislé výbery potvrdili, že medzi 6.A a 6.B triedou na začiatku výskumu nebol štatisticky významný rozdiel vo vedomostnej úrovni žiakov v predmete Technická výchova (Tab. 2).

\section{Štatistická verifikácia hypotézy $H 1$}

Prvou testovanou hypotézou bola hypotéza H1: Žiaci, ktorí používali stavebnicu Dominika, dosiahnu na konci experimentálneho vyučovania vo vedomostnom didaktickom teste vyšší výkon ako žiaci vyučovaní tradične $\mathrm{v}$ kontrolnej skupine.

$\mathrm{V}$ tomto prípade sme použili meranie na začiatku v 6.A a v 6.B triede a na konci výskumu $\mathrm{v}$ experimentálnej a v kontrolnej skupine. Pred začatím experimentu sme pomocou vstupného testu zist'ovali, či je vedomostná úroveň žiakov
6.A triedy a $6 . \mathrm{B}$ rovnaká. Porovnanie výsledkov zo vstupného testu medzi triedami 6 . A a 6 . B je zobrazené v grafe č. 1 , z ktorého vidíme, že je len minimálny rozdiel vo frekvenciách dosiahnutých bodov dane hodnotiacej škály. Ide takmer o identické výkony, s tým že v 6.A triede sa $\mathrm{v}$ škále priemerných a nadpriemerných výkonov pohybovalo o 5 žiakov viac ako v 6.B triede.

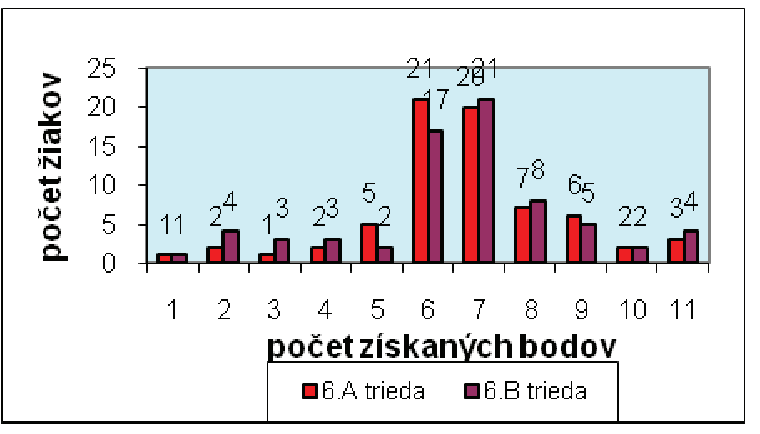

Graf 1: Porovnanie frekvencií dosiahnutých bodov vo vstupnom vedomostnom teste technickej výchovy medzi 6.A a 6.B triedou.

Naším ciel'om bolo zistit', či na konci experimentu bude alebo nebude štatisticky významný rozdiel vo vedomostiach kontrolnej a experimentálnej skupiny. Po aplikovaní stavebnice Dominika v predmete Technická výchova $\mathrm{v} 6$. roč. ZŠ, sme overovali úroveň vedomostí žiakov kontrolných a experimentálnych skupín výstupným testom.

\begin{tabular}{|c|c|}
\hline & Testovacie štatistiky \\
\hline $\mathrm{D}$ & 0,57143 \\
\hline $\mathrm{z}$ & 3,3810 \\
\hline $\mathrm{p}$ & $0,0000-$ význ. \\
\hline
\end{tabular}

Tab 3: Výsledky v kontrolnej a experimentálnej skupine na konci experimentu.

\begin{tabular}{|c|c|c|}
\hline Skupina & AM & SD \\
\hline Kontrolná & 5,971 & 2,934 \\
\hline Experimentálna & 8,957 & 3,192 \\
\hline
\end{tabular}

Tab 4: Štatistické parametre aritmetický priemer a smerodajná odchýlka v kontrolnej $a v$ experimentálnej skupine.

Z tabul'ky 3 vidiet', že vypočítaná hodnota pravdepodobnosti $\mathrm{p}$ je menšia ako zvolená hladina významnosti 0,01 . Na zvolenej hladine významnosti 0,01 to znamená, že je štatisticky významný rozdiel vo vedomostnej úrovni žiakov v postteste. Porovnanie obidvoch skupín nám pre lepšiu názornost' prehl'adne uvádza graf č. 2, z ktorého vidíme rozdiel medzi nimi. Pre signifikantnost' tohto rozdielu sme zist'ovali, či 
tento rozdiel je štatisticky významný na hladine významnosti 0,01 . Výpočtom sme zistili, že tento rozdiel je štatisticky významný $v$ prospech experimentálnej skupiny s tým, že tento rozdiel nie je náhodný, ale je zákonitý, spôsobený jednoznačne nami navrhnutou a použitou stavebnicou Dominika (Tab. 3).

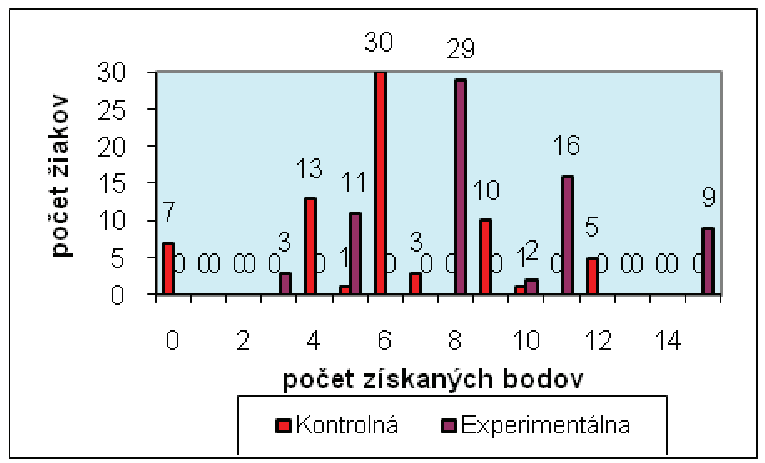

Graf 2: Porovnanie frekvencii dosiahnutých bodov vo výstupnom vedomostnom teste technickej výchovy medzi kontrolnou a experimentálnou skupinou.

Vidíme, že graf ako aj aritmetické priemery (Tab. 4) ukazujú posun v smere k vyšším bodovým hodnotám $\mathrm{v}$ prospech experimentálnej skupiny. Môžeme konštatovat', že hypotéza H1 sa potvrdila na hladine významnosti 0,01 . Práca so stavebnicou Dominika neovplyvnila úroveň vedomostí žiakov v experimentálnej skupine, ale štatisticky významne na hladine významnosti 0,01 ovplyvnila ich úroveň technického myslenia a technickej predstavivosti.

\section{Štatistická verifikácia hypotézy $\mathrm{H} 2$}

Druhou testovanou hypotézou bola hypotéza H2: Žiaci, ktorí používali stavebnicu Dominika, dosiahnu na konci experimentálneho vyučovania v praktickom didaktickom teste vyšší výkon ako žiaci vyučovaní tradične v kontrolnej skupine.

$\mathrm{V}$ tomto prípade sme použili meranie len na konci výskumu $\mathrm{v}$ experimentálnej a $\mathrm{v}$ kontrolnej skupine. V priebehu nášho výskumu sme navrhli praktický didaktický test týkajúci sa technického tvorivého myslenia. Naším ciel'om bolo zistit', či na konci experimentu bude alebo nebude štatisticky významný rozdiel v úrovni technického tvorivého myslenia kontrolnej a experimentálnej skupiny.

\begin{tabular}{|c|c|}
\hline & Testovacie štatistiky \\
\hline $\mathrm{D}$ & 0,45714 \\
\hline $\mathrm{z}$ & 2,704 \\
\hline $\mathrm{p}$ & $0,0000-$ význ. \\
\hline
\end{tabular}

Tab 5: Výsledky v kontrolnej a experimentálnej skupine na konci experimentu.

\begin{tabular}{|c|c|c|}
\hline Skupina & AM & SD \\
\hline Kontrolná & 1,600 & 1,398 \\
\hline Experimentálna & 2,929 & 1,026 \\
\hline
\end{tabular}

Tab 6: Štatistické parametre aritmetický priemer a smerodajná odchýlka v kontrolnej a v experimentálnej skupine.

Z tabul'ky 5 vidiet', že vypočítaná hodnota pravdepodobnosti $p$ je menšia ako zvolená hladina významnosti 0,01 . To znamená, že je štatisticky významný rozdiel $\mathrm{v}$ úrovni technického tvorivého myslenia žiakov $\mathrm{v}$ postteste. Porovnanie kontrolnej a experimentálnej skupiny nám uvádza graf 3 . Najpočetnejšia skupina v kontrolnej skupine je len v pásme podpriemeru. V experimentálnej skupine je vychýlenie gausovej krivky doprava. Znamená to, že väčšina žiakov v experimentálnej skupine dosiahla vo výstupnom praktickom teste vyššie skóre ako priemerné. Na základe zistených údajov tvrdíme, že aplikovaním nami navrhnutej stavebnice Dominika vo vyučovaní sa štatisticky významne zlepšila úroveň technického tvorivého myslenia žiakov experimentálnej skupiny.

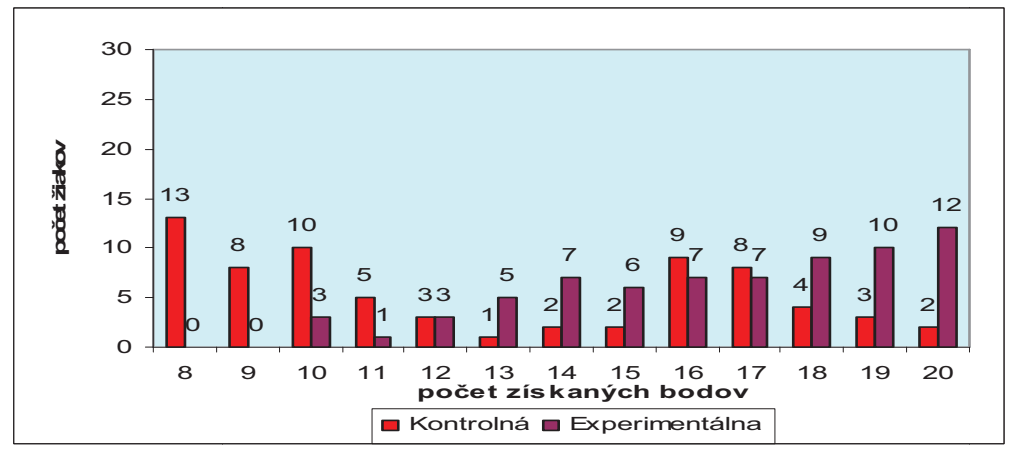

Graf 3: Porovnanie frekvencií dosiahnutých bodov vo výstupnom praktickom teste technickej výchovy medzi kontrolnou a experimentálnou skupinou. 
Vidíme, že graf ako aj aritmetické priemery (Tab. 6) ukazujú posun v smere k vyšším bodovým hodnotám. Môžeme konštatovat', že hypotéza $\mathrm{H} 2$ sa potvrdila.

\section{Štatistická verifikácia hypotézy H3}

Tret'ou testovanou hypotézou bola hypotéza H3: Žiaci, ktorí používali stavebnicu Dominika, dosiahnu na konci experimentálneho vyučovania v Teste diferenciácií schopností - priestorové vzt'ahy vyšší výkon ako žiaci vyučovaní tradične v kontrolnej skupine.

$\mathrm{V}$ tomto prípade sme použili meranie na začiatku v 6.A a v 6.B triede a na konci výskumu $\mathrm{v}$ experimentálnej a v kontrolnej skupine. Pred začatím pedagogického experimentu sme pomocou vstupného štandardizovaného Testu diferenciácie schopností - priestorové vzt’ahy (TDS-PV) zist'ovali, či je úroveň priestorovej predstavivosti žiakov 6.A triedy a 6.B rovnaká. Výsledky porovnania úrovne priestorovej predstavivosti žiakov 6.A a 6.B triedy sú spracované v tabul'ke č. 7.

\begin{tabular}{|c|c|}
\hline & Testovacie štatistiky \\
\hline $\mathrm{D}$ & 0,25714 \\
\hline $\mathrm{z}$ & 1,521 \\
\hline $\mathrm{p}$ & 0,0200 -nevýzn. \\
\hline
\end{tabular}

Tab 7: Výsledky výberovej sk. na začiatku exp.

\begin{tabular}{|c|c|c|}
\hline Skupina & AM & SD \\
\hline 6. A trieda & 19,929 & 9,935 \\
\hline 6. B trieda & 15,300 & 8,832 \\
\hline
\end{tabular}

Tab 8: Štatistické parametre aritmetický priemer a smerodajná odchýlka v 6.A a v 6.B triede.

$\mathrm{Z}$ tabuliek 7 a 8 je vidiet' mierny rozdiel i ked' nie významný na hladine významnosti 0,01 $\mathrm{v}$ prospech 6.A triedy. $\mathrm{Z}$ tohto dôvodu sme ako experimentálnu skupinu určili 6.B triedu.

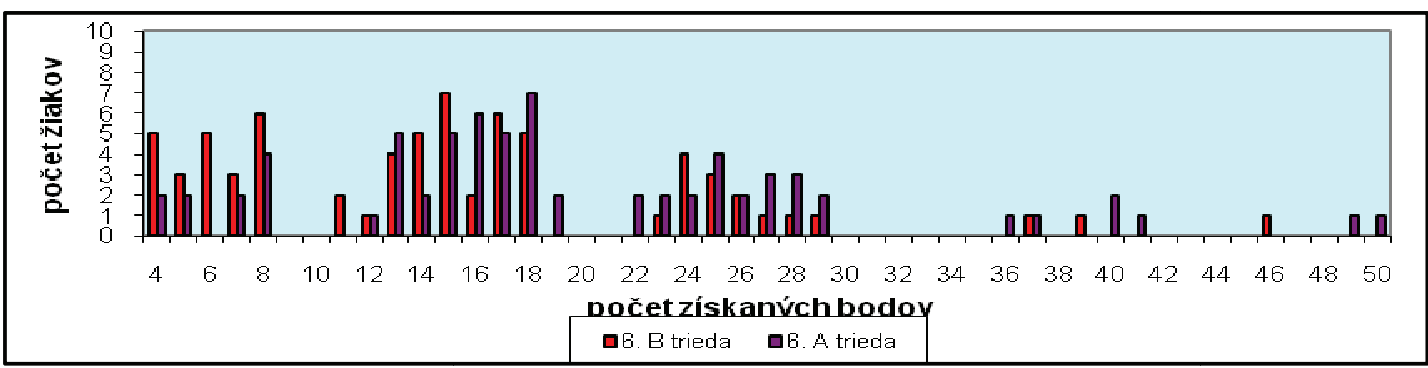

Graf 4: Porovnanie frekvencií dosiahnutých bodov vo vst. teste TDS-PV medzi triedou 6. A a tr.6. B.

Porovnanie výsledkov zo vstupného testu medzi triedami 6.A a 6.B je zobrazené v grafe č. 4, z ktorého vidíme, že je len minimálny rozdiel vo frekvenciách dosiahnutých bodov danej hodnotiacej škály. Ide takmer o identické výkony, s tým, že lepšie výkony sú v prospech triedy 6.A, v oblasti nadpriemerných výkonov. Zist'ovali sme, či tento rozdiel je štatisticky významný na hladine významnosti 0,01 . Výsledky sú uvedené v tabul'ke 8.

Po aplikovaní stavebnice Dominika v predmete Technická výchova v 6. ročníku základných škôl, sme overovali úroveň priestorovej predstavivosti žiakov kontrolných a experimentálnych skupín pomocou výstupného testu.

\begin{tabular}{|l|r|}
\hline & Testovacie štatistiky \\
\hline $\mathrm{D}$ & 0,68571 \\
\hline $\mathrm{z}$ & 4,057 \\
\hline $\mathrm{p}$ & $0,0000^{* *}$ \\
\hline
\end{tabular}

Tab 9: Výsledky v kontrolnej a experimentálnej skupine na konci experimentu.

\begin{tabular}{|c|c|c|}
\hline Skupina & AM & SD \\
\hline Kontrolná & 22,114 & 12,380 \\
\hline Experimentálna & 44,857 & 12,127 \\
\hline
\end{tabular}

Tab 10: Štatistické parametre aritmetický priemer a smerodajná odchýlka v kontrolnej $a v$ experimentálnej skupine.

Z tabul'ky č. 9 vidíme, že situácia vo výstupnom teste je jednoznačná. Rozdiel v dosiahnutých výsledkoch vo výstupnom teste medzi experimentálnou a kontrolnou skupinou je štatisticky významný na hladine významnosti 0,01 v prospech experimentálnej skupiny. Vo výstupnom teste sa u žiakov v kontrolnej skupine úspešnost' riešenia úloh pohybovala rovnako ako vo vstupnom teste v prvej polovici bodovej škály. U žiakov v experimentálnej skupine úspešnost' riešenia úloh pohybovala $\mathrm{v}$ druhej polovici zo 60 bodovej škály testu. Pri porovnaní kontrolnej a experimentálnej skupiny možno konštatovat', že dosiahnutý rozdiel je v prospech experimentálnej skupiny. Porovnanie obidvoch skupín nám 
uvádza graf č. 4, z ktorého jasne vyplýva daný rozdiel. Pre signifikantnost' tohto rozdielu sme zist'ovali, či tento rozdiel je štatisticky významný na hladine významnosti 0,01 . Výpočtom sme zistili, že tento rozdiel je štatisticky významný v prospech experimentálnej skupiny s tým, že tento rozdiel nie je náhodný, ale je zákonitý, spôsobený jednoznačne nami navrhnutou a použitou stavebnicou Dominika.

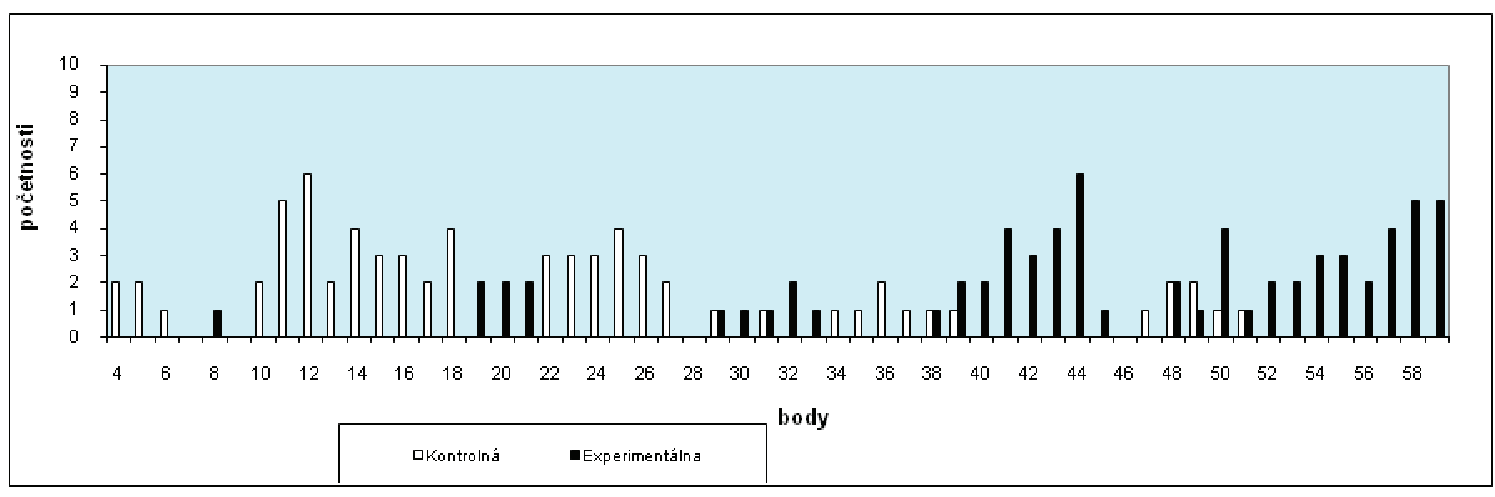

Graf 4: Porovnanie frekvencií dosiahnutých bodov vo výstupnom teste medzi kontrolnou a experimentálnou skupinou.

\section{Záver}

Edukačná stavebnica v obale - Dominika má všetky funkcie učebných pomôcok, pričom má uplatnenie vo všetkých etapách edukačného procesu v materských a základných školách, ako aj v kluboch a vol'nočasových zariadeniach. Na základe analýzy skúmanej problematiky na základných školách sme zistili, že žiaci 6 . ročníka, ktorí používali stavebnicu Dominika dosiahli vo vedomostnom teste, v TDS-PV a v praktickom teste významne lepšie výsledky ako žiaci, ktorí so stavebnicou Dominika nepracovali. Výsledky z pedagogického výskumu ukázali, že stavebnica Dominika rozvíja technické tvorivé myslenie.

\section{Literatúra}

1. BALÁŽOVÁ, E.: Hračky vškole. Banská Bystrica: VH, 2004. ISBN 80-968131-3-7.

2. DUURIŠ, M.: Miesto a význam didaktických testov vo vyučovaní technickej výchovy v 5. 9. ročníku základnej školy. In: Technické vzdelanie ako súčast' všeobecného vzdelania. Banská Bystrica: UMB FPV v Banskej Bystrici, 1999. ISBN 80-8055-292-4.

3. GAVORA, P.: Úvod do pedagogického výskumu. Bratislava: UK, 2001. ISBN 80-2231628-8.

4. KERLINGER, F. N.: Základy výskumu chování. Praha: Academia, 1972. Bez ISBN

5. KUZMA J.: Vzdelávací štandard s exemplifikačnými úlohami z technickej výchovy - technickej zložky pre 2. stupen̆ základnej školy. Bratislava: MŠ SR, 2002. 36 s. [dostupné na internete]
6. LATIPKA, M.: Tvorba a použitie didaktických testov. Bratislava: SPN, 1988. ISBN 80-08-00782-6.

7. POLČIC, L. Úžitkový vzor - edukačná stavebnica $v$ obale. In: IKT $\mathrm{v}$ technickom vzdelávaní, 23. medzinárodná vedecko odborná konferencia, Odborná monografia z príspevkov. Banská Bystrica: FPV, 2007. s. 284-288, ISBN 978-80-8083-529-3, EAN 978-80-8083-529-3.

8. UHEL, J.: Možnosti presahov a ich aplikácií vo vyučovaní. In: História, súčasnost' a perspektívy učitel'ského vzdelávania. Banská Bystrica: PF UMB, 2005. s. 443-444, ISBN 80-8083-107-6.

9. VAŠAŠOVÁ, Z. Tvorivost' a kognitívne procesy. In: Človek v spoločnosti. B. Bystrica: FHV, 2006. s. 140 - 156. ISBN 80-8083-291-9.

10.VAŠAŠOVÁ, Z. Tvorivá osobnost' a kognitivne procesy. In: Človek v spoločnosti. Človek v edukačnom prostredí. 1. čast'. Banská Bystrica: UMB FHV, 2007. s. 140 - 159 ISBN 978-80-8083-423-4.

\section{PaedDr. L'udovít Polčic, PhD.}

Doc. PaedDr. Milan Ďuriš, CSc.

Katedra techniky a technológií

Fakulta prírodných vied UMB

Tajovského 40, 974 01, Banská Bystrica, SR

Tel.: +421 484467217

E-mail: polcic@fpv.umb.sk,

duris@fpv.umb.sk

Www pracovisko: www.fpv.umb.sk/kat/kt 